\title{
Kalam and Falsafa: Unity in the Collision
}

\author{
Maryam Zianshina \\ History of Philosophy Department \\ Peoples' Friendship University of Russia \\ 6 Miklukho-Maklaya Str. \\ Moscow, Russia \\ E-mail: zimaryam@yandex.ru
}

\begin{abstract}
The article shows the origins of the birth of kalam and falsafa. The reasons for the divergence of these two areas of Islamic philosophy, and also how the historical context influenced the formation of the basic ideological basis of these directions. In addition, the article points out the details of each of the currents. The way of incorporated into the Muslim civilization philosophical ideas of antiquity. It will also make mention the main figures who developed these two currents of medieval Arab thought.
\end{abstract}

Keywords-kalam; falsafa; ummah; Sunnis; Shiites; theology

\section{INTRODUCTION}

It was after Prophet Mohammad's death in 632 that Muslim Ummah (Ummah is a religious community. The term took shape when Prophet Mohammed was engaged in preaching and when the community united by the common religion arose) began to experience the first major difficulties. Any problems concerning the new religion aspects had been settled by Allah's ambassador himself. Mohammad's death threw the issue of the Prophet's vicar election into sharp relief. The first schism in Muslim Ummah was emerging. Some believed that the nephew and husband of his beloved daughter Fatima Ali could only become the legal successor to Mohammad who did not have any male successor. This enclave is commonly called Shiites. Others thought this issue should be settled by Ummah, and any dignified man of Quraysh tribe, the tribe from which the Prophet himself originated, was eligible to become a calif. This community was called Sunnis.

These two political oppositions clashed for power in 655 , in the first civil war in the history of the Muslim civilization [1]. Many trends and branches will emerge in Islam later, and all of them will have the only aim - to head the Ummah, to struggle for power.

As noted above, the differences arose in the first years of the community's existence as an independent unit. The pursuit of power resulted in ideological opposition, not only in armed conflicts. The Koran interpretation was the major challenge. The Koran is the fundamental book for all Muslims. The authority and divine origin of the Sacred Writings are unfailing. However, its correct interpretation is still a problem. Curiously enough, this problem became very acute in the period when the Muslim civilization expanded to other territories with rich history and culture, well-developed economic and political system, with their long-standing beliefs, and to the territories where many "People of the Book", Jews and Christians, resided, so they were supposed to be incorporated into the Muslim civilization by Islamification [2]. The only way to achieve this goal was by version understanding of the Koran, by assuming its allegoric interpretation. The legitimacy of claims to power was also associated with the expanded understanding of the Holy book.

\section{BEGINNING OF KALAM}

The onset of Kalam was concurrent with Arabic conquests of the 7 th - 9th centuries, too. Kalam was initially the term with a broad meaning, which denoted any religious or philosophical reasoning, including reasoning of Christian and Jewish theologists, and as the ideas developed and proponents appeared, Kalam took shape as an independent Islamic philosophic trend [3]. It is in Kalam that assimilated the principles of law established in conquered territories that we find the first philosophical reasoning. The judicial and legal judgment on what it right or wrong in a person's actions was determined by reference, first of all, to the Koran, the authority of which was supplemented by the existing tradition in the first three centuries or so from Islam emergence. Any doubts in their interpretation could be settled by consensus, such as the authority making a conclusion (ijmā'). Independent inferences (qiyās) were issued similarly, by a lawyer, but as a last resort only, and were supposed to be implemented via the Scripture interpretation, excluding any other standard that was independent of the Koran.

Thus, initially kalam arises and develops on the background of various religious and political groups, such as Kharijites, Kadarites, Jabrites, and Murjites.

\section{EVOLUTION OF KALAM}

Kalam evolution was accompanied by the need to eliminate contradictions in Islam's metaphysical world outlook. By applying the same principles, early theologians worded the system of doctrines on the God and the world, which were incorporated into the Scripture. Mu'tazilahs of the 7 th to 9 th centuries made certain assumptions relying on common sense. For instance, the Koran writes that a man 
will be punished by Allah on the Judgment Day for all of his earthy atrocities, but the common-sense prompts that the perfect God will not punish a man for the actions beyond the man's control. Consequently, a man should have the right to choose his actions, and the God does not pre-determine the human choice. Thus, the reconciliation of such features of the God as omniscience and omnipotence also triggered the theological evolution.

The kalam general subject was originally aimed at solving the problem of power and responding the time challenges that the new religion faced. But later the kalam perspectives spread to such questions as the problem of God's attributes, eternity and the Quran creation problems, problem of the world creation, and problem of will and predestination freedom. The problem of will and predestination freedom was dominant at the early stage of the Islam development prior to kalam strengthening as the dominant "theology" (the golden age of Mu'tazilah falls on the first half of the 9th century, when it was enjoyed by the Abbasid caliphs support). The first generation of Muslims, relying on the idea of an unlimited divine force and power, believed that a man is obliged to perform some actions, rather than exercise them freely, i.e. the destiny of the person is predetermined. Exponents of this direction are called Jabrites. In their opinion, the only true power that is able to act is God, and therefore, this means that a man obeys this will and is not able to act freely. This movement included Jahmis (Jahma b. Safwan followers), followers of al-Husayn al-Najjar, Dirar b. 'Amra and al-Ash'ari, who adhered to various versions of the kasb concept. The kasb is a term that designates the concept according to which there are two "doers" (fa'ilan) participating in human actions - the God who creates them, and the person who "appropriates" them, which was a compromise between the Jabrites and the Kadarites, that means the God creates an action, and a man appropriates it., On the other hand the Kadarites believed that a man has freedom of will and acts by himself. Such thinkers as Ma'bad al-Juhani (killed in 699-700 or 703-04), Gaylan ad-Dimashqi (killed in 742), and al-Hasan al-Basri (killed in 642-728) supported that belief. This resulted into an important ethical conclusion: The God is All-good and he creates only goodness; and all evil in the world comes from a man as a result of his free will. The well-known Islamic theologian Ibn Batta al-'Ukbari (916-997), the prominent ideologist of the Hanbali, wrote in his work "Interpretation and Explanation of the Fundamentals of Sunnah and Religion" about the Kadarites and Jabrites the following: "Among their leaders there are the supporters of freedom of will (Kadarites) - Ma'bad al-Juhani, Gaylan al-Kandari, Sumama b. Ashras, Amr b. 'Ubayd, Abu'l-Khuzayl al-'Allaf, Ibrahim an-Nazzam, Bishr b. al-Mu'tamir, at the head of the group;, there are other people of disbelief and delusion (Jabrites) among them. They include al-Hasan b. 'Abd alWahhab al-Jubba'i and Abu'l-Anbas al-Saymari" [4]. Later Mutazilites were formed from the midst of the Kadarites and proclaimed the reasoning power as the criterion of truth.

In the same period, the interest in the Greek tradition intensified, in particular, in the regions where Christianity, which had adopted and used the Greek philosophy for its needs, had prevailed before Islam dissemination. The "servant" of the Christian tradition came to penetrate the Muslim civilization.

Even though the Islamic theology early development occurred without a direct reference to the philosophy based on the Greek tradition (Falsafa), but Mu'tazilah inherited several derivative notions from it, such as the "God" and the "man", or via the Christian theology that, in turn, adopted the notions from Greek philosophy precisely. Mu'tazilah and ascharites used the tools of Aristotle's logic in their discussions and disputes, but none of the parties called the Greek philosophy as the source of true ideas of the God and the world. A question arise: to what extent did the Greek tradition influence the Kalam establishment? By the time Falsafa became widely known among the academic community of that time, it was unlikely to influence the establishment of the Islamic doctrine that had already taken shape.

\section{KALAM AND FALSAFA: THE FIRST COLLISION}

Falsafa emerged a bit later than Kalam, in the 8th century, in connection with active translations. A great number of philosophic books were translated into Arabic from 750 to 1,000 A.C. An intellectual of that time was impressed by the depth of understanding and the power of reasoning in works by Greek philosophers, in particular, Plato and Aristotle. One of Falasafa's key claims against Kalama proponents was reduced to the reasoning method: the Greek tradition followers regarded dialectic (as understood by Aristotle) used by Mutakallims as the inferior reasoning method. But is there actually a great difference for achievement of the goal the Mutakallims set: initially, they sought to educate popular masses of the new religion on market places; so dialectic opinions suited this goal perfectly. Moreover, then Kalam took the assumptions for its reasoning from religious texts or statements that are beyond doubt, though cannot be logically proven, because of divine premises. Falasifah handled the rationale that is beyond doubt from the logical point of view. Thus, both of them regarded their rationale as correct.

\section{KALAM AND FALSAFA: DEVELOPMENT OF THE CONFLICT}

Could Falsafa be dangerous for the theology already developed by Mutakallims, with its claims to be scientific, with its ambitions to know the true about the world, which show the same confidence as medicine, mathematics, astronomy and other Greek sciences, which managed to occupy their niche in the intellectual space of the Muslim world of the 9th century? Possibly, Mutakallims and Falasifah tried to avoid direct conflicts from the mid-9th century to the mid-11th century, though their relations were tense. This conflict between Falsafa and Kalam was postponed for two centuries for several reasons. Firstly, Arabic philosophers, limited by a certain ideology, expressed their ideas with caution and tried to align them with Islam's main doctrines as much as possible. According to this, AlFarabi's and Ibn Sina's neo-Platonic mysticism was presented as a kind of Sufism; none of them denied the 
resurrection (on the Judgment Day) in public, and both of them gave a reasonable explanation of the Prophet's ascension. Secondly, the Ascharite school of Kalam became the prevalent one after Nizamiya, an educational center in Bagdad in the Seljukide Era (1065), was founded as a school of Sunnite theology. There were more liberties at Fatimides.

The difficult period for Falsafa began. It is more frequently that theologists voiced the reproaches that Falsafa had too much freedoms, expressing its opinion on such things as the World Creation, which had already been reflected in the Scripture.

Nonetheless, a major blow on Falsafa was delivered by al-Ghazali (1058-1111), who had already criticized Falsafa proponents and, mastering the context perfectly, beat the enemy with the enemy's weapons in the Philosophers' Inconsistency book (1095). This is a strikingly polemic paper, in which he attached Aristotle's and Arabic Muslim Peripatetic's philosophy. By stating that they relied on conjectures and presumptions, rather than on true and positive knowledge in making their judgments, al-Ghazali proves their views on the world's eternity, the world creation, proving the God's existence, the God's attributes, the Divine knowledge, movement, the possibility of wonders, the immortality of human soul, resurrection and post-mortem existence are inconsistent. In 1096 to 1106, in the Criteria to Distinguish Islam from Schismatic Doctrines (Kitāb fay șalat-tafriqa baynal-Islām waz-zandaqa), he substantiated the impossibility for Oriental peripatetics to interpret the Scripture allegorically.

Nobody in Mashriq dared disputing with al-Ghazali. But somebody was supposed to do so, if Falsafa wanted to survive in Muslim realities. Almost eighty years later, in Maghreb, the Andalusian thinker of Ibn Rushd weighted in on the debate with al-Ghazali at the pages of his work, Inconsistencies of Inconsistency. Despite almost a century that had passed, the debate remained topical and could not be avoided in order to continue the positive philosophic discourse.

Ibn Rushd's attempt at reconciling two dissenting systems of thinking was harmonious with the entire Islamic culture that is fundamentally syncretical. That's why this trend towards reconciling the seemingly intransigent basics, like religion and philosophy, culminated in Ibn Rushd's treatises. Perhaps, it is because of this trend that Falsafa found its niche in the medieval Arabic Muslim civilization.

It is for several centuries that the Malikite Shariat law school that relies on imam Malik ibn Anas' doctrine prevailed in Andalusia and covered all fields in making a judgment on morals and social situations. Therefore, Andalusian Malikites believed they did not need any religious dogmas other than those that can be derived from the Koran. Mu'tazilah came up in Andalusia at approx. 10th century but were regarded as misbelievers that were persecuted then.

For instance, Ibn Massara (883-931), Andalusia's first Sufi philosopher, and his disciples could survive by living as hermits only.
The situation remained unchanged under Almoravides. Ali ibn Yussouf under his reign (1106/7-1142/3) adopted the policy to encourage faqih, study Malikite dogmas, and prohibit theology. Even al-Ghazali's works were burned then.

It should have seemed philosophy was unable to exist in conditions when theology was persecuted; but on the contrary, it revived in Almeria. The Sufi's Order developed and displayed successorship; so, the main provisions of Ibn Massara's doctrine were restored from the large textual fragments quoted by Ibn Arabi (1165-1240).

Ibn Badzha (approx. 1070 - 1139) was Andalusia's first philosopher who referred to Plato's and Aristotle's works directly.

Another Oriental peripatetic in Andalusia, Ibn Tufal (approx. 1110 - 1185), spent a greater part of his life under Almoravides, though he wrote his outstanding work, The Story of Haya, Yakzan's Son, describing the natural development of humans and human thinking, under Almokhades.

Thus, under Almoravide's complicated reign, vivid interest in philosophy was seen; the teachers who prepared the appearance of the last peripatetic, Ibn Rushd, by their works.

Though philosophers survived but preferred not to express their thoughts openly in this difficult environment.

In this situation, the opposition to Almorovide's rule was inevitable, and in 1146 Abd-al-Mumin (1101-1163) put an end to Almoravide's dynasty, and Almokhades began ruling the region.

Under al-Mumin, ascharites' and al-Ghazali's works were available to the educated public. Al-Mumin himself adhered to Zahiriyah madhhab. In his new empire, Malikites accounted for the majority of personnel in his civil administration, and he had to take their interests into account.

Though Falsafa, as a philosophy focusing on Antique ideals, dated back to the 9th century in Mashriq and found its new continuation in Maghreb in the 11th century. Despite its deviation from the mainstream thinking tradition, it continued to evolve under Almoravides.

The trend towards thought transition from Mashriq to Maghreb has its historic and cultural pre-requisites, despite the unfavorable environment for the philosophical thought in Maghreb, as it used to be for Falsafa in Mashriq [5].

\section{KALAM AND FALSAFA STRIVE FOR EACH OTHER}

Since the 13th century, Kalam and Falsafa strive for each other: Kalam is drifting towards the Oriental peripatetism of Ibn Sina's school, which was prepared by works of ashShakhrastani and Fahr ad-din ar-Razi on the part of Mutalakkims and by Nasir ad-dina at-Tusi on the part of Falasifah. As a result, according to Ibn Khaldun, "Kalam and Falsafa issues in the works of the latest [Mutakallims] mixed up, making these sciences indistinguishable." In new and newest time, Kalama, first of all Mutazilism, inspired rationalists who tried not to conflict with the Islamic dogma 
basics, including such Muslim reformers as Jamal ad-din alAfghan and Mohammad Abdo, in the Muslim world [6].

\section{CONCLUSION}

Thus, the origins of Kalam and Falsafa are the single point of the need to find answers to questions the young religion poses, which could not be fully satisfied by the Koran and the Sunnah. Despite the long way, Kalam and Falsafa differences in methodology and ideology began leveling out by the 13th century when the positions of the Arabic Caliphate as a political and military power were weakening.

\section{REFERENCES}

[1] Oliver Limen, Introduction to Classical Islamic Philosophy. Moscow, 2007, p. 20.

[2] N.S. Kirabaev, Political Thought in medieval Islam. Moscow, 2005, p. 27.

[3] G. F. Hourani. Background in Islamic philosophy / Averroes: On the harmony of religion and philosophy. 1961, pp. 2-6.

[4] Ibn Batta al-'Ukbari. Interpretation and explanation of the bases of Sunnah and religion / Reader of Islam. M., 1994, p. 98.

[5] George F. Hourani. Background in western Islam / Averroes: On the harmony of religion and philosophy. 1961, pp. 6-18.

[6] Islam: Encyclopedic Dictionary. Moscow, 1987, p. 128. 